\title{
Madridge
}

madridge Journal of Nanotechnology \& Nanoscience

nterconne

Mini-Review Article

Open Access

\section{Nanomedicine: Will it be able to overcome Multiple Drug Resistance in Cancer?}

\author{
Sten Friberg* \\ DBane' rgatan 21 VII, SE-115 22 Stockholm, Sweden
}

Article Info

*Corresponding author:
Sten Friberg
Bane'rgatan $21 \mathrm{VII}$
SE-115 22 Stockholm
Sweden
E-mail: Proband@Telia.com

Received: September 9, 2016

Accepted: September 12, 2016

Published: September 17, 2016

Citation: Friberg S. Nanomedicine: Will it be able to overcome Multiple Drug Resistance in Cancer?. Madridge J Nanotechnol Nanosci. 2016; 1(1): 13-13.

doi: $10.18689 /$ mjnn-1000105

Copyright: (c) 2016 The Author(s). This work is licensed under a Creative Commons Attribution 4.0 International License, which permits unrestricted use, distribution, and reproduction in any medium, provided the original work is properly cited.

Published by Madridge Publishers

\section{Summary}

At present, every third individual in the Western world is diagnosed with a cancer at some point in their lives. In spite of great advances in oncology in recent decades, around $50 \%$ of these individuals will die from their diseases. The great majority of these deaths are caused by cancer cells endowed with multiple drug resistance (MDR). These cells are not eliminated by present-day therapies, and new strategies for general oncologic treatment are needed. The shape of such new treatments is emerging, and such treatments will likely be highly individualized, but at the same time highly complex and costly.

Keywords: Nanomedicine; Cancer; Therapeutics; Multi drug resistance (MDR).

\section{Multimodality is mandatory, and the treatment steps will be sequential.}

\section{The plausible major steps are likely to be:}

1. Blocking of the genes responsible for MDR.

2. Kiling of the adult cancer cells that are protecting the malignant stem cells. With the genes blocked in Step 1, the adult cancer cells will be more susceptible to toxic drugs.This will allow smaller amounts of therapeutic drugs to be used, leading to fewer toxic side effects.

3. The dead adult cancer cells must be removed to expose the dormant cancer stem cells. Dormant cancer cells are believed to be unaffected by present-day oncologic therapies.

4. Initiation of proliferation among the cancer stem cells which will make them susceptible to education or killing.

5. Killing of the malignant stem cells, or educating them to enter permanent dormancy and thus render them harmless.

For these five steps, the medical profession is already in possession of most of the needed therapeutic agents. However, some of these agents are toxic when given intravenously in humans, and some of them are inactivated during the transport in the blood. Nanoparticles might offer a dual benefit by protecting the patient from the agent, and simultaneously protecting the agent from the patient.

What is lacking is knowledge of the time needed for each step and of the potential side effects for each step.

Effective targeting methods currently exist for superficial tumours (both primary and secondary), but not for deep-seated cancers.

A more detailed version of this summary is found in:"Nanomedicine: will it offer possibilities to overcome multiple drug resistance in cancer? J NANOBIOTECHNOLOGY (2016); 14: 17. 